\title{
FORMS OF CHILD ABUSE IN THE POOR FAMILY IN PURWOKERTO, INDONESIA
}

\author{
Tri Na'imah, Retno Indriyani \\ Faculty of Psychology - Universitas Muhammadiyah Purwokerto, Jl. Raya DukuhWaluh PO Box 202 Purwokerto, Indonesia \\ Corresponding Author Email: trinaimah@ump.ac.id
}

This is an open access article distributed under the Creative Commons Attribution License, which permits unrestricted use, distribution, and reproduction in any medium, provided the original work is properly cited

\section{ARTICLE DETAILS}

\section{Article History:}

Received 01 June 2019 Accepted 11 July 2019

Available online 23 August 2019

\section{ABSTRACT}

This study aims to examine the forms of mothers' violence against children among the poor families in Purwokerto, Indonesia. The participants in the study were chosen by purposive sampling technique; they were from poor family in Purwokerto, Indonesian. The data collection methods used were interviews and observations. The data validity test used triangulation technique of data source and method. Results showed : the forms of violence against children among the poor families can be categorized into 3, namely : First, physical abuse, the mother's behavior in the form of pinching, punching, slapping, confining the child in the bathroom. Second, psychological abuse, which is the behavior of the mother in the form of talking with harsh words and comparing children with peers, calling bad names, scolding and rejecting the presence of children, Third, economic abuse, i.e. mother's behavior in the form of ignoring the needs of food and clothing, and forcing their children to work.

\section{KEYWORDS}

Violence Against Children, Physical Abuse, Psychological Abuse, Economic Abuse, Poor Family

\section{INTRODUCTION}

Children are the future hope of Indonesian parents. They should be protected, cared, and loved to grow optimally. However, situations such as economic difficulties, work difficulties, familial disputes with spouse, and physical exhaustion can be a source of stress that triggers adults to be more vulnerable to do a violence [1]. Violence against children is any form of painful treatment either physical or emotional, sexual, negligent, commercial exploitation or other exploitation, resulting in injury or harm to the child's health, survival, development, or his/her dignity [2].

In Law no. 23 of 2002 Article 1 paragraph 2 on Child Protection, it states that "Every child has the right to survival, growth and development and the right for protection from violence and discrimination". Yet, in reality the number of child violence in Indonesia has always increased. In 2011, the children who were victims of the violence were 2178 , and they, in 2014, increased to 5066 [3].

Types of violence against children include physical, sexual, economic, and emotional abuse [4]. Physical abuse is the most easily identifiable type of violence as it can be identified through threatening, intimidating, punching, kicking, punching, slapping, pushing behavior that results in physical injury or death in children [5]. Sexual violence may be physical or verbal, such as the pre-contact sexual treatment between a child and an adult through words, touch, visual images, or the direct treatment of sexual contact between a child and an adult. Economic violence in children can be either the abandonment of the necessities of life or the employment of children [6]. Emotional violence involves all behaviors of adult children that result in inhibiting the children's non-physical development [4].

Children who are mistreated by their parents cannot properly fulfill and perform their developmental tasks, potentially suffering from posttraumatic stress disorder, aggression, emotional and mental health problems, such as anxiety and depression, social development problems and behavioral disorders [7]-[8]. Children of violence victims also experience economic impact in a long time. Adults who have difficulty in education and work experience some childhood violence [9]. Besides, the family poverty can also cause children to experience stress and anxiety in their lives [10].

Ironically the perpetrators of child abuse are usually those who have close relationships with children, such as family, teachers and peers. This happens because many parents think violence against children is a natural thing. Perpetrators consider violence to be part of disciplining children. In fact, the individuals who are most responsible for welfare, protection and optimizing the growth of children are the parents. In most cases of violence against children, the nurturing mother is often the perpetrator.

Parents that have financial difficulties can project the problem to the child [11]. Children are often involved in fulfilling the economic needs of the family, even in illegal activities such as child prostitution. This condition often occurs in families with economic difficulties [5]. Therefore, violence against children needs to be handled comprehensively.

\subsection{Child Abuse}

Violence as a term that is full of meaning and meaning "suffering", both from the perspective of psychology and law. In this concept contained the meaning of human behavior that can cause suffering for others (person / group) [12]. Child abuse is doing something or failing to do something that results in harm to a child or puts a child at risk of harm. Child abuse can be physical, sexual or emotional. Neglect, or not providing for a child's needs, is also a form of abuse. World Health Organization also explained that child abuse or maltreatment constitutes all forms of physical and/ or emotional ill-treatment, sexual abuse, neglect or negligent treatment or commercial or other exploitation, resulting in actual or potential harm to the child's health, survival, development or dignity in the context of a relationship of responsibility, trust or power [13]. Signs of child abuse is : 1) shows sudden changes in behaviour or school performance, 2) Has not received help for physical or medical problems brought to the parents' attention, 3) Has learning problems (or difficulty concentra-ting) that cannot be attributed to specific physical or psychological causes, 3) Is 
always watchful, as though preparing for something bad to happen, 4) Lacks adult supervision, 5) Is overly compliant, passive, or withdrawn, 6) Comes to school or other activities early, stays late, and does not want to go home [12]. Based on the description, then child abuse has serious physical and psychological consequences which adversely affect the health and overall well-being of a child. Most abused children suffer greater emotional than physical damage. Although most children suffer more than one type of abuse. A physically abused child, for example, is often emotionally maltreated as well, and a sexually abused child may also be neglected.

\subsection{Forms of Child Abuse}

Child abuse categorized childhood maltreatment into four basic types: physical abuse, sexual abuse, emotional abuse, and neglect [14]. Each type is described below:

1) Physical Abuse: Physical violence against children is mostly done by parents in disciplining children. Physical violence is the use of physical aggression as a means of threatening and intimidation [5]. Physical indicators of abuse include bruises, lacerations, swollen areas, and marks on the child's face, head, back, chest, genital area, buttocks, or thighs. Wounds like human bite marks, cigarette burns, broken bones, puncture marks, or missing hair may indicate abuse. The occurrence of physical violence against children is usually triggered by behaviors that trigger the emotions of his parents, such as crying, asking for snacks, pooping in any place, vomiting anywhere or breaking the parent's favorite stuff. Physically abused children experience various undesired consequences, ranging from soft tissue injuries to deaths with unknown causes. Loss of memory, growth retardation, speech delay, social withdrawal, limited friends and peer relationships, academic failure and suicidal tendencies, as well as, interpersonal, cognitive, emotional and behavioral problems, are observed in these children [5].

2) Sexual Abuse: Sexual abuse is using sexual activity as a means of threatening, intimidation and control. Sexual abuse can be physical or verbal. Exposing a child to sexual language, rape with or without consent, using a child in pornography or for prostitution, displaying pornographic materials, indecent exposure, physical contact with a child's genitals, and inducement or coercion of a child to touch an adult's genitals are all considered as sexual abuse [5]. Among published studies of adults reporting retrospectively on their own childhood, prevalence rates of childhood sexual abuse among men range from $1 \%$ using a narrow definition of sexual contact involving pressure or force - to $19 \%$, where a broader definition was employed [15]

3) Emotional Abuse: Defining emotional or psychological abuse is therefore very difficult. Furthermore,the consequences of psychological abuse. Therefore, the marker of emotional abuse is less clear, compared to other types of abuse. Emotional child abuse is maltreatment which results in impaired psychological growth and development. It involves words, actions, and indifference. Abusers constantly reject, ignore, belittle, dominate, and criticize the victims. This form of abuse may occur with or without physical abuse, but there is often an overlap. Emotionally neglected and abused children are exposed to attitudes and behaviors that have negative impacts or are deprived of the attention, love and care they need, and therefore, they are psychologically traumatized according to social and scientific standards [16].

\section{THE PRESENT STUDY}

This research is important as a basis for identification of children at risk as victims of violence and the perpetrator's family. Violent acts are a behavior that must not be done to any children because they have the right to grow and develop optimally both physically, mentally, socially, and spiritually. This research is expected to reveal the forms of the violence against children.

\section{METHOD}

\subsection{Participants and Procedure}

The informants in this study are divided into the primary and secondary informants. The primary informants was chosen by purposive sampling technique, those are mothers from families received a social allowance from Indonesian government and they have children aged 3-5 years. The secondary informants are family members and neighbors who know them. The profiles of the primary informants can be seen in Table 1, while the profiles of secondary informants are presented in the Table 2.
The focus of this research is the forms of violence against children done by mothers of poor families in Purwokerto, Indonesia.Case study was employed as an approach in this qualitative study, because the researcher considers that cases of violence by mothers are clearly identifiable special cases. To produce a complete finding, the researchers describe the forms of violence against children that have been revealed by researchers when studying the case. The researcher focused on the overall information about the forms of violence that led to the occurrence of violence against children. In the final stages, researchers elaborate the meaning of the cases.

Table 1: Profiles of Primary Informants

\begin{tabular}{|l|l|l|l|}
\hline Characteristics & Informant 1 & Informant 2 & Informant 3 \\
\hline Initials & SL & ST & SY \\
\hline Age & 34 yrs & 37 yrs & 38 yrs \\
\hline Ethnicity & Javanese & Javanese & Javanese \\
\hline Age of marriage & 10 yrs & 13 yrs & 17 yrs \\
\hline Job & laborer & housewife & housewife \\
\hline Education & $\begin{array}{l}\text { Senior high } \\
\text { school }\end{array}$ & $\begin{array}{l}\text { Junior high } \\
\text { school }\end{array}$ & $\begin{array}{l}\text { Elementary } \\
\text { school }\end{array}$ \\
\hline
\end{tabular}

Table 2: The Profiles of Secondary Informants

\begin{tabular}{|l|l|l|l|}
\hline Characteristics & Informant 1 & Informant 2 & Informant 3 \\
\hline Initials & DD & AM & SA \\
\hline Age & 34 yrs & 37 yrs & 38 yrs \\
\hline Sex & Male & Female & Female \\
\hline Ethnicity & Javanese & Javanese & Javanese \\
\hline Age of marriage & 10 yrs & 13 yrs & 17 yrs \\
\hline Job & Trader & housewife & housewife \\
\hline $\begin{array}{l}\text { Relation } \\
\text { primary } \\
\text { Informant }\end{array}$ & husband & neighbor & neighbor \\
\hline
\end{tabular}

\section{MEASURES}

Interviews and observations were used to reveal data on the forms violence by mothers. Triangulation techniques of data sources and methods are used to test the data validity. The data of interviews were compared to those of observation. Furthermore, the data obtained from the primary informants were verified by the data collected secondary informants. They were then analyzed by a technique of interactive model of data analysis, meaning that activities in the data analysis were done interactively and run continuously till the data were completely saturated. The stages in the data analysis are data collection, data reduction, data display, and conclusion drawing / verification [17].

\section{RESULTS AND DISCUSSION}

Based on the thematic analysis of the data, the forms of violence against the children in the poor families can be categorized into 3, namely: 1 ) physical abuse, 2) psychological abuse, and 3) economic abuse.

\subsection{Physical Abuse}

For informants, managing anger is very difficult, especially if the child shows problematic behavior. The violence was done spontaneously by the informant, as SL said: "Spontaneously I pinched or slapped. Children cannot understand the condition. I am dizzy thinking about the daily needs, but they even whined for toys ". The secondary informants DD reported that that SL often pinches the child when the child is crying for snack or toy. Usually SL does it while she shows her anger to the child. It is like her habit to vent her anger.

SL has high school education and works as daily laborer. Despite having a high school education, she lacks the understanding of good parenting. She sometimes realizes that she cannot play a role as a mother, since she has to work for helping the husband to meet the needs of family life. The husband can understand her violent behavior to child; it is due to the children's failure to understand their family economic condition.

Another informant, ST, also has a habit of violence against her child. ST said she is not satisfied if she has not pinched her child. Her son is a troublemaker; he is lazy to study, likes to buy daily snacks. She does not feel any guilty, and the violence has been a daily habit. This behavior is known by AM as a neighbor. As a neighbor she cannot prevent the treatment and protect the child. Sometimes she feels sorry to listen ST's son crying. She reported that the violence sometimes goes more terribly 
like banging the child's head against the wall, locking his son in the bathroom, and even watering overhead.

The similar case is also identified in SY. She committed physical violences in the form of pinching, slapping, punching, and punching. She has experienced as a victim of domestic violence committed by her husband. She only graduated from an elementary school and was considered stupid by her husband. Hence, she projects her anger to her children. SA, as a neighbor, often hears her argument with the husband and it involves their little son.

\subsection{Psychological Abuse}

In this theme, the violence is done in verbal and nonverbal forms. SL committed a psychological violence in the form of talking roughly and comparing the study scores of her child to his peer. ST did a psychological violence in the form of harsh speech, saying the words that make the child psychologically depressed, snapped, and compared the study score of her child with his peer. While the SY informant committed psychological violence in the form of talking harshly, yelling, calling with a bad name, scolding, and ignoring the child. All informants perceive the children as the additional burden for the the family needs. Therefore, the child's mistakes easily trigger the informant to commit the violences.

That is why the way the informant speaks loudly and straightforwardly to his or her children is considered normal. They assume they have to say anything as it is, no need to cover. SA is SY's neighbor, often hearing quarrels in the family. The child in the family has been used to hearing harsh words from his parents.

Religious education is not taught by the three informants. Their children are sent to the nearest school. Two informants, ST and SY, are housewives who have a lot of time at home, but they never accompany their children in home learning. They do not pay any attention to the times when their children have to come home from school, to study at home and to take a rest.

\subsection{Economic Abuse}

All informants did not meet the basic needs of children, including the need for food, school equipment and school uniforms. SY even expelled her child and made him a beggar. SL worked to meet the needs of the family, but the needs of food and of the school uniforms were not fulfilled. ST has a disharmony in her family; she has a problem with her in-laws. Her family have to pay the in-law's debt; the husband' income is prioritized to pay the debt. Thus, the children's needs become neglected.

The informants of this study are mostly not well-educated. Low-educated individuals tend to treat children more abusively than highly educated people. [18]. This is because the level of education is the foundation of how a person behaves. The low level of education will make it difficult for person to understand the message or information conveyed. Education can change the knowledge, attitude and skills of human beings. Thus it can be interpreted that the behavior of violence conducted by the informants in this study is due to the low knowledge of child development. In addition, they also come from poor families. The family poverty, besides having a bad influence on the social psychological aspects, increases the number of violence and children negligent [9].

The results showed that all informants committed physical abuse to theie children. The impact of physical violence can be felt directly by the child, such as pain in the body. In addition there is increasing evidences that child abuse and neglect increase the negative consequences for children in some aspects of development, including psychological, social, behavioral (crime and violence), academic, and interpersonal functions [19].. This condition is apparent in child victims who show poor physical health, they often complain of illness, making them to leave from school. The physical violence in children can make them feared of their own parents [20]. This makes a disharmonic relation between parents and their children; it makes a gap between them.

The research findings also show that informants provide less support for their children's education. Parents with low economics generally do not realize the importance of seeking education or how to struggle for selfdevelopment so that their children are lack of understanding about the concept of life [20]. The constantly increasing factors of poverty and pressures of life, accompanied by anger or disappointment to the spouse, and the powerlessness in dealing with economic problems make it easy for the parents to vent their emotions to the people around them. In this case the child is regarded as a weak member and is considered to be fully owned by the parents, making them the easiest target of their parents [21]. child to be targeted in sparking his anger. Children from poor families are lack of support from their parents, causing problems in their development. The parents should direct their children's study and play times and provide s clear instruction on the time-division of learning and play at home. This will improve their ability to manage time at home, so that they will have a self-discipline[22].

All informants also committed verbal violence in the form of rude words, threatening, comparing their school achievement to their peers. They always shout out as an expression of their emotion. A verbal abuse can adversely affect the child's development. It does not leave any visible marks, but its emotional impact can destroy their lives [23].

Involving children in family's economic fulfillment is only done by SY. Abused and neglected children experience major and lasting economic consequences. According to the theory of poverty, the fundamental factor of the working children is poverty. Most parents' income with their working children is very little. Poor households or economically disadvantaged families will mobilize their family resources collectively to meet the needs of daily living. Such conditions make the young children forced to work.[9].

Based on these findings, the children from poor families in Purwokerto Indonesia, are at risk of experiencing barriers in their development. According to the theory of socialization of Parental Acceptance-Rejection Theory (PAR), children that are rejected by their parents tend to be hostile, aggressive, less independent, and have problems in self-esteem. The children, as the victims of violence, tend to be emotionally unstable and have a negative outlook on life [23]. Children who are victims of abuse experience losses in various domains. The most severe and irreparable is the loss of childhood. Loss of selfconfidence, and desperation.

The findings of the study also show that all informants give reasons for their violence; they are confused about fulfilling the basic needs of the family. They also feel burdened with their own children's needs. It is only an informant, SY, who has a different reason; she acts the violence as an outlet of her anger to her husband who always abuses her. One the factors triggers the occurrence of violence is a family factor. It includes a chaotic family life in which there is no mutual love and appreciation, their members do not appreciate the housewife role, and there is a lack of familiarity and of social networking relationships [24]. In this case, the family context is a large family, including the relationship between the inlaws. If the relationship is negative, the problem will easily come into into the nuclear family. In turn, the background of bad relationships will trigger the parents to do violence against their children.

The limitations of this study were the small number of participants. The subjective experience of the informants can only be understood in their own context. Subsequent research needs to examine a violence against children in cultural studies and in the context of mental health with more informants. Finally, the findings of the forms of the violence against children in the poor families need to be followed up by formulating some intervention programs.We want to declare that there are no conflict of interest related to this publication and no financial support may affect the results of this study.

\section{CONCLUSIONS}

Based on thematic analysis of the data, the forms of child abuse committed by mothers in poor families can be categorized into 3, namely: First, physical abuse, namely pinching, hitting, slapping, locking children in the bathroom, watering, banging their heads against the wall. Second, psychological abuse, which is talking in harsh words and comparing children with their peers, calling badly, scolding, and rejecting the presence of children, ignoring their education, ignoring children's health. Third, economic abuse, namely ignoring food and clothing needs, and employing children.

\section{REFERENCES}

[1] Widiastuti, D., and Rini S. 2005. Deteksi Dini, Faktor Risiko, dan Dampak Perlakuan Salah pada Anak. Jurnal Sari Pediatri, 7 (2), 105-112.

[2] Fakih, M. 2013. Analisis Gender dan Transformasi Sosial. Yogyakarta: Pustaka Pelajar.

[3] Setyawan, D. 2015. KPAI: Pelaku Kekerasan Terhadap Anak Tiap Tahun Meningkat, dalam http://www.kpai.go.id.

[4] Taner, Y., Gokler, B. 2004. Child neglect and abuse: Psychiatric sides (In Turkish). Hacettepe Medical Journal, 35, 82-86. 
[5] Biçakçi, M.Y., Er, S., and Neriman A. N. 2016. An Overview of Child Neglect and Abuse: Types, Causes, Impact and Prevention, Ethno Med, $10(2), 221-228$.

[6] Gokce, T. 2010. The Story and Effects of Home Violence on Psychology of Samsun Primary School Teachers (In Turkish). Thesis, Published. Samsun: Ondokuz Mayis University.

[7] Dong, M., Giles, W.H., Felitti, V.J., et al. 2004. Insights into causal pathways for ischemic heart disease: adverse childhood experiences study. Circulation. 110,1761-1766.

[8] Bulik, CM, Prescott CA, Kendler KS. 2001. Features of childhood sexual abuse and the development of psychiatric and substance use disorders. British Journal of Psychiatry. 179, 444-449.

[9] Currie, J., and Widom, C.S. 2010. Long-Term Consequences of Child Abuse and Neglect on Adult Economic Well-Being Child Maltreat. 15(2), 111-120.

[10] Na'imah, T. 2010. Studi Tentang Strategi Wanita dalam Pengembangan Karakter Anak dari Keluarga Miskin di Purwokerto Selatan. Psycho Idea, 8 (1), 53-71.

[11] Bilge, F. 2006.Child neglect and abuse, violence in schools and juvenile delinquency. In: S Ercetin (Ed.): Education and Violence. Ankara: Pegem Publications, pp. 219-260.

[12] Gupta, N., and Aggarwal, N.K. Child abuse, Delhi Psychiatry Journal, 15, (2), 416-419. 2012.

[13] World Health Organization. 1999. Report of the Consultation on Child Abuse Prevention; Geneva, http://www.who.int/violence_ injury_prevention/violence/neglect/en/.

[14] Child Welfare Information Gateway. 2011. About CAPTA: A Legislative history. Washington, DC: U.S. Department of Health and Human Service, Children's Bureau.
[15] Goldman, J.D., and Padayachi, U.K. 1997. The Prevalence and Nature of Child Sexual Abuse in Queesland, Australia, Child Abuse and Neglect, 21, 489-498.

[16] Kara, B., Bicer, U., Gokalp, A.S. 2004. Child abuse (In Turkish). Journal of Child Health and Diseases, 47, 140-151.

[17] Miles, M.B., Huberman,A.M, and Saldana, J. 2014. Qualitative Data Analysis, A Methods Sourcebook, Edition 3. USA: Sage Publications.

[18] Sumayku, G.P.S., Tomuka, D., and Kristanto, E. 2016. Hubungan usia waktu menikah dengan kejadian kekerasan pada anak di Kota Manado Bulan Oktober 2014-Oktober 2016. Jurnal e-Clinic (eCl), 4 (2), 1-8.

[19] Gilbert, R., Widom, C.S., Browne, K., Fergusson, D.M., Elspeth, W., Janson, S. 2009. Child Maltreatment 1: Burden and consequences of child maltreatment in high-income countries. The Lancet.373,68-81.

[20] Dutta, N. 2018. Street Children In India: A Study On Their Access To Health And Education, International Journal of Child, Youth and Family Studies, 9(1), 69-82.

[21] Fitriana, Y., Pratiwi, K., Sutanto, AV. 2015. Faktor-Faktor yang Berhubungan dengan Perilaku Orang Tua dalam Melakukan Kekerasan Verbal Terhadap Anak Usia Pra-Sekolah. Jurnal Psikologi Undip, 14 (1), 81-93.

[22] Na'imah, T., and Suwarti. 2014. Model Pemberdayaan Keluarga Dengan Pendekatan Improvement Dan Berbasis Masalah Psikososial Anak Dari Keluarga Miskin, Sainteks, XIII, (1), 83 - 90.

[23] Loh, J., Calleja, F., and Restubog, S.L.D. 2011. Words That Hurt: A Qualitative Study of Parental Verbal Abuse in the Philippines, Journal of Interpersonal Violence, 26(11), $2244-2263$.

[24] Hartini, L. 2009. Agresi Anak yang Tinggal dalam Keluarga dengan Kekerasan Rumah Tangga. Jurnal Penelitian Fakultas Psikologi Universitas Gunadarma, 1-15.

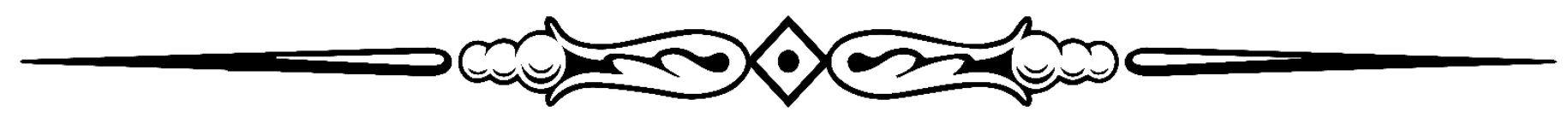

